\title{
Kościół rzymskokatolicki w poszukiwaniu interkomunii z Kościołami odmiennych tradycji liturgicznych
}

Słowem „Eucharystia” (w języku greckim „eucharystia” oznacza „dziękczynienie”) określamy sakrament, który w Kościele rzymskokatolickim nazywany jest najczęściej „Mszą świętą” albo „ofiarą Mszy świętej”, w Kościołach protestanckich „Wieczerzą Pańską”, a w Kościołach wschodnich „Bożą Liturgią”. Ukazanie problemu wspólnoty eucharystycznej Kościołów chrześcijańskich należy poprzedzić krótkim przedstawieniem nauki katolickiej na temat Eucharystii. Na tej podstawie będzie można określić, jakie są aktualne możliwości i perspektywy wspólnego stołu eucharystycznego Kościoła obrządku łacińskiego z Kościołami zachowującymi inne tradycje liturgiczne. Ten „wspólny stół” zaczyna się od uczestnictwa w Komunii świętej poza swoim Kościołem, a zmierza do pełnego spotkania we wspólnej celebracji sakramentu Eucharystii. Przedstawione zostanie zarówno oficjalne stanowisko Kościoła rzymskokatolickiego w sprawie interkomunii na podstawie dokumentów, jak i różne, mniej oficjalne, oddolne inicjatywy mające na celu przyspieszenie zjednoczenia chrześcijan wokół Eucharystii.

\section{Eucharystia w nauczaniu Kościoła rzymskokatolickiego}

W Kościele łacińskim teologiczna refleksja nad Eucharystią rozwinęła się w drugim tysiącleciu, już po odłączeniu się Kościoła prawosławnego w 1054 roku. Na sformułowanie nauki Kościoła dotyczącej tego zagadnienia miało także wpływ wyodrębnienie się Kościołów protestanckich w pierwszej połowie XVI wieku. Nauczanie o Eucharystii objęło wyjaśnienie sposobu obecności w niej Chrystusa, natury eucharystycznej przemiany, związku Eucharystii z ofiarą krzyżową Chrystusa, zbawczych skutków Komunii dla przyjmującego oraz odpowiedź na pytanie, kto ma prawo sprawować ją w sposób ważny. Jeszcze przed Soborem Trydenckim Kościół wyraźnie określił, że w Eucharystii obecne jest prawdziwe Ciało i Krew Jezusa Chrystusa oraz że pod każdą postacią przebywa „całość Ciała i Krwi Chrystusa” (Sobór w Konstancji w latach 
1414-1418)1. Sobór Trydencki (1545-1563) podsumował dotychczasowe nauczanie o Eucharystii i sformułował dogmatyczne podstawy jego dalszego rozwoju, do których Kościół odwołuje się do dziś. Najważniejszym stwierdzeniem soboru było uznanie, że Chrystus obecny jest w Eucharystii prawdziwie, rzeczywiście i substancjalnie (vere, realiter et substantialiter) oraz że obecność ta ma swój początek w chwili, gdy zostaną wypowiedziane nad chlebem i winem słowa konsekracji, którymi są słowa Jezusa z ostatniej wieczerzy². Dokonuje się wówczas przemiana chleba i wina w Ciało i Krew Chrystusa, którą Kościół zdefiniował jako przeistoczenie - transubstantiatio ${ }^{3}$. W odpowiedzi na ataki protestantów sobór wyjaśnił także, jak Kościół katolicki rozumie związek Eucharystii z ofiarą Chrystusa. W trydenckiej Nauce o najświętszej ofierze Mszy świętej czytamy, że Msza święta jest przedstawieniem (repraesentatio), pamiątką (memoria) i zastosowaniem (aplicatio) ofiary krzyża, dokonanej jeden jedyny raz przez Chrystusa 4 .

Sobór Trydencki zainicjował także reformę liturgii, która przejawiła się w opracowaniu i wydaniu nowych ksiąg liturgicznych (w tym mszału w 1570 roku) używanych w Kościele aż do Soboru Watykańskiego II (1962-1965). Ostatni sobór podjął kolejną, odważną reformę liturgii Mszy świętej w celu uczynienia jej bliższej współczesnym wiernym oraz umożliwienia im czynnego i świadomego w niej uczestnictwa. Sobór Watykański odnowił również naukę o Eucharystii, powracając do jej źródeł biblijnych i patrystycznych z pierwszych wieków chrześcijaństwa.

Soborowa konstytucja o liturgii świętej naucza: „Zbawiciel nasz podczas Ostatniej Wieczerzy [...] ustanowił Eucharystyczną Ofiarę Ciała i Krwi swojej, aby w niej na całe wieki, aż do swojego przyjścia, utrwalić Ofiarę Krzyża i tak [...] Kościołowi powierzyć pamiątkę swej Męki i Zmartwychwstania: sakrament miłosierdzia, znak jedności, węzeł miłości,

${ }^{1}$ Sobór Powszechny w Konstancu (1414-1418), Dekret o Komunii św. pod jedna postacia, [w:] Breviarium fidei. Wybór doktrynalnych wypowiedzi Kościoła, oprac. S. Głowa, I. Bieda, VII, 282. Naukę o tym, że cały Jezus obecny jest zarówno pod postacią chleba, jak i pod postacią wina powtarza unijny Sobór Florencki. Zob. XVII Sobór Powszechny Florencki (1438-1445), Dekret dla Ormian (1439), [w:] Breviarium fidei, dz. cyt., VII, 285.

${ }^{2}$ XIX Sobór Powszechny Trydencki, Dekret o Najświętszym Sakramencie, [w:] Breviarium fidei, dz. cyt., VII, 289. Zob. W. Granat, Eucharystia. Misterium Bożej obecności, Sandomierz 2001, s. 40.

${ }^{3}$ Ojcowie Soboru Trydenckiego w 1551 roku stwierdzili, że przeistoczenie jest przemienieniem „,całej substancji chleba w Ciało i całej substancji wina w Krew Chrystusa”, przy czym postaci chleba i wina pozostają bez zmian - XIX SoBór PowsZECHNY TrYDENCKI, Dekret o Najświętszym Sakramencie, [w:] Breviarium fidei, dz. cyt., VII, 292. Terminu „transsubstancjacja” zaczęto używać już w drugiej połowie XII w. Por. E. Ozorowski, Nauka o Eucharystii w wypowiedziach Urzędu Nauczycielskiego Kościoła, „Ateneum Kapłańskie” 101 (1983), s. 202.

${ }^{4}$ Por. A. Adam, Corso di liturgia, Brescia 1995, s. 153-154. 
ucztę paschalną, w której pożywamy Chrystusa, w której dusza napełnia się łaską i otrzymuje zadatek przyszłej chwały"5.

Do dominującego w okresie przedsoborowym określenia Mszy świętej jako ofiary Sobór Watykański dodaje i stosuje nowe, z których najbardziej znaczące dla jej rozumienia to uczta paschalna, pamiątka, dziękczynienie (Eucharystia) ${ }^{6}$. W doskonalszy sposób tłumaczy się po Soborze obecność ofiary i dzieła zbawczego Chrystusa w Eucharystii. W czasie Mszy świętej ofiara Chrystusa nie powtarza się, ale uobecnia. Dzieje się to przez skuteczną, liturgiczną pamiątkę (gr. anamnesis) Jego męki, którą On polecił przypominać swoim uczniom. W każdym sprawowaniu Eucharystii Kościół jest wierny temu poleceniu ${ }^{7}$. Kościół rzymskokatolicki uważa, że mają prawo ją sprawować tylko oficjalni następcy apostołów Chrystusa (biskupi) i ich pomocnicy (prezbiterzy). Tak postanawia nowe prawo kanoniczne: przewodniczyć Eucharystii i dokonywać przeistoczenia może tylko ważnie wyświęcony szafarz, którym jest biskup bądź prezbiter ${ }^{8}$.

Jeden ze znaczących współczesnych badaczy Eucharystii, Johannes Betz (†1984), opierając się na tekstach Nowego Testamentu, przedstawia następująco zagadnienie realnej obecności Chrystusa i Jego dzieła w Eucharystii: „Nowy Testament ogłasza identyczność darów eucharystycznych z rzeczywistą osobą Jezusa, który dla nas i dla naszego zbawienia ofiaruje się w krwawej śmierci krzyżowej - i tu daje się na pokarm w sakramencie, aby dać nam tak zrealizowane odkupienie. Odkupienie więc to właściwie On sam, Jego wcielona osoba, dokonująca naszego zbawienia. $\mathrm{Z}$ realną obecnością tej osoby jest więc ściśle związana także aktualna obecność Jego historycznego dzieła zbawczego. Eucharystia staje się w ten sposób sakramentalną obecnością całego wydarzenia zbawczego, któremu na imię Jezus, w którym Jego osoba i dzieło tworzą nierozerwalną jedność"9.

Niemiecki teolog chce wykazać, że w celebracji Eucharystii mamy do czynienia nie tylko z samą statyczną obecnością Jezusa, ale także z dokonanym przez Niego dziełem zbawczym, którego kulminacją była ofiara na krzyżu złożona za nas i dla naszego zbawienia ${ }^{10}$. Nauczanie soborowe zwraca uwagę na różne sposoby obecności Chrystusa podczas Mszy świętej i do obecności pod postaciami eucharystycznymi dodaje Jego obecność

${ }^{5}$ Sobór WATYKańSKi II, Konstytucja o liturgii świętej Sacrosanctum concilium, 47.

${ }^{6}$ Por. J. JANICKI, Msza święta. Liturgiczne ABC, Warszawa 1993, s. 10-12.

${ }^{7}$ Por. A. Skowronek, Eucharystia, sakrament wielkanocny, Włocławek 1998, t. 5, s. 40.

${ }^{8}$ Por. Codex Iuris Canonici auctoritate Ioannis Pauli PP. II promulgatus, can. 900.

${ }^{9}$ J. BETz, Die Eucharystie in der Zeit der griechischen Väter, t. 2.1: Die Realpräsenz des Leibes und der Blutes Jesu im Abendmahl nach dem Neuen Testament, Freiburg i. Br. 1964, s. 201.

${ }^{10}$ Por. A. Adam, Corso di liturgia, dz. cyt., s. 153. 
w zgromadzeniu wiernych, w osobie odprawiającego i w Słowie Bożym ${ }^{11}$. Wprawdzie obecność Zbawiciela pod postaciami eucharystycznymi uznana zostaje za obecność rzeczywistą w najwyższym stopniu, nie oznacza to jednak, jak uczy papież Paweł VI, że inne sposoby są nierzeczywiste ${ }^{12}$. Jan Paweł II kontynuuje nauczanie Soboru Watykańskiego i Pawła VI, rozwijając eklezjologiczny aspekt Eucharystii i dodając, że Eucharystia jest tajemnica, która przerasta nasze myśli i może być przyjęta tylko przez wiarę ${ }^{13}$.

\section{Interkomunia z Kościołami wschodnimi}

Kościół rzymskokatolicki łączy z Kościołami na Wschodzie wspólne dziedzictwo wiary i jedności pierwszego tysiąclecia, co dotyczy zwłaszcza Kościołów prawosławnych, które przyjmują w pełni orzeczenia pierwszych soborów powszechnych. Kościoły katolicki i prawosławny uznają wzajemnie ważność swoich sakramentów na podstawie nieprzerwanej sukcesji apostolskiej w odniesieniu do kapłaństwa i Eucharystii. Na tej podstawie Kościół rzymskokatolicki uważa, że można dopuścić wiernych obydwu wyznań do udziału w kulcie liturgicznym, a nawet do przyjmowania Komunii świętej w nie swoim Kościele (interkomunia) ${ }^{14}$. Rodzi się także nadzieja, że kiedyś oba apostolskie Kościoły zjednoczą się na nowo we wspólnej celebracji Eucharystii (intercelebracja) ${ }^{15}$.

Spróbujmy najpierw ukazać perspektywy intercelebracji. Zarówno katolicyzm, jak i prawosławie wyrażają opinię, że zanim nastąpi wspólna celebracja eucharystyczna, między obydwoma Kościołami musi nastąpić pełna zgoda w kwestii dogmatów ${ }^{16}$. Aktualne stanowisko Kościoła katolickiego w tej sprawie zawiera ekumeniczne nauczanie Jana Pawła II. W encyklice Ecclesia de Eucharistia stwierdza on, że jedność Kościoła „koniecznie domaga się pełnej komunii w zakresie wyznania wiary, sakramentów i władzy kościel-

${ }^{11}$ Por. Sobór WatykańSKi II, Konstytucja o liturgii świętej Sacrosanctum concilium, 7.

${ }^{12}$ Por. PAwet VI, Instrukcja Eucharisticum misterium, [w:] To czyńcie na moja pamiątę. Eucharystia w dokumentach Kościoła, opr. J. Miazek, Warszawa 1987, s. 162.

${ }^{13}$ Por. Jan Pawe飞 II, Encyklika Ecclesia de Eucharistia vivit. O Eucharystii $w$ życiu Kościoła, Kraków 2003, 15.

${ }^{14}$ Por. Papieska Rada ds. Popierania Jedności Chrześcijan, Dyrektorium w sprawie realizacji zasad i norm dotyczacych ekumenizmu (25 marca 1993), 122, [w:] Ut unum. Dokumenty Kościoła katolickiego na temat ekumenizmu 1982-1998, S. C. Napiórkowski, J. i K. Leśniewscy, Lublin 2000, s. 30-101.

${ }^{15}$ Por. K. StARczewski, Nauka o Eucharystii w wybranych wyznaniach chrześcijańskich i chrześcijańskich dialogach ekumenicznych, Kielce 2006 (mps), s. 81-86.

${ }^{16}$ Por. W. Hryniewicz, Czy wspólnota Stołu Pańskiego jest już możliwa?, [w:] To czyńcie na moja pamiatkę. Eucharystia w perspektywie ekumenicznej, pod red. nauk. L. Górki, Warszawa 2005, s. 248. 
nej"17. Dopóki ta więź nie zostanie na nowo przywrócona, dopóty nie będzie możliwe koncelebrowanie tej samej liturgii eucharystycznej. W wypadku, gdyby taka wspólna celebracja zaistniała przedwcześnie, mogłaby okazać się przeszkodą do osiągnięcia pełnej komunii oraz wprowadzić bądź uwiarygodnić różne nieścisłości dotyczące prawd wiary. Papież przypomina, że droga ku pełnej jedności może być realizowana tylko w prawdzie ${ }^{18}$.

Na drodze do intercelebracji z prawosławnymi stoją także przeszkody natury eklezjologicznej. Każda Eucharystia, choć jest sprawowana we wspólnocie lokalnej, objawia się jako obraz i rzeczywista „obecność jednego, świętego powszechnego i apostolskiego Kościoła"19. W związku z tym komunia kościelna jest także komunią z lokalnym biskupem oraz z papieżem. Nieporozumieniem byłoby więc, gdyby Eucharystia, będąc sakramentem jedności, była sprawowana bez łączności z biskupem Rzymu. Jan Paweł II stwierdza, że komunia z następcą św. Piotra jest źródłem i podstawą jedności zarówno kolegium biskupów, jak i wiernych, a każda celebracja eucharystyczna wyraża powszechną komunię z papieżem oraz z całym Kościołem ${ }^{20}$. W przypadku „Kościołów chrześcijańskich odłączonych od Rzymu” taka celebracja może jednak obiektywnie przywoływać tę komunięę1.

Interkomunia pomiędzy Kościołami rzymskokatolickim i wschodnim teoretycznie wydaje się łatwiejsza do osiągnięcia, gdyż wzajemnie uznają one zarówno sakrament kapłaństwa, jak i Eucharystii. Dla jej zaistnienia muszą być jednak spełnione określone warunki uzgodnione $\mathrm{z}$ hierarchią danego wyznania $^{22}$. Pełna realizacja interkomunii, poza przypadkiem zaspokojenia

${ }^{17}$ JAN PaWeE II, Encyklika Ecclesia de Eucharistia vivit, dz. cyt., 44.

${ }^{18} \mathrm{~W}$ adhortacji apostolskiej Ecclesia in Europa Jan Paweł II stwierdza, że działanie na rzecz jedności „musi się łączyć z poszukiwaniem prawdy i ma się odbywać przez dialog i konfrontację”. Dzięki temu możliwy będzie dalszy postęp w przezwyciężaniu rozbieżności, które nadal są powodem podziału chrześcijan. Por. JAN PAwEŁ II, Adhortacja apostolska Ecclesia in Europa. O Jezusie Chrystusie, który żyje w Kościele, jako źródło nadziei dla Europy, Kraków 2003, 30.

${ }^{19}$ Jan PaweE II, Encyklika Ecclesia de Eucharistia vivit, dz. cyt., 39.

${ }^{20} \mathrm{~W}$ liście apostolskim Mane nobiscum Domine papież dodaje, że Eucharystia, będąc źródłem jedności Kościoła, staje się także jej najlepszym przejawem i objawieniem komunii. Jedność, o której mówi papież, oparta jest na hierarchii i „na świadomości różnych ról i posług", które są potwierdzane w modlitwie eucharystycznej. Chodzi tu o wspominanie papieża oraz biskupa diecezjalnego. Por. JAN PAwEŁ II, List apostolski Mane nobiscum Domine, Watykan 2004, 21.

${ }^{21}$ JAN PAWE⿺ II, Encyklika Ecclesia de Eucharistia vivit, dz. cyt., 39.

${ }^{22}$ Por. W. Hanc, Interkomunia - możliwości i perspektywy, [w:] Eucharystia i postannictwo. Wieczerza Pańska w dialogu chrześcijan, pod red. L. Górki, W. Hryniewicza, Warszawa 1987, s. 105. 
poważnej potrzeby duchowej, nie będzie niestety możliwa, dopóki nie zostaną zacieśnione widzialne więzi komunii kościelnej ${ }^{23}$.

Sobór Watykański II w Dekrecie o katolickich Kościołach wschodnich Orientalium Ecclesiarum postanawia, że chrześcijanom wschodnim można udzielić sakramentu Eucharystii. Według nowego Dyrektorium w sprawie realizacji zasad i norm dotyczacych ekumenizmu (25 marca 1993) muszą oni spełnić jednak dwa warunki: z własnej woli o to prosić oraz być do tego odpowiednio przygotowanymi ${ }^{24}$. Ze strony szafarzy katolickich nowe dyrektorium wymaga znajomości dyscypliny Kościołów wschodnich i unikania wszelkiego prozelityzmu ${ }^{25}$. Dekret Orientalium Ecclesiarum stwierdza, że również i katolicy mogą prosić o ten sakrament szafarzy niekatolickich, ale tylko wtedy, gdy w ich Kościele jest on udzielany ważnie. Tu jednak także stawia się warunek: można uczynić tak tylko wtedy, gdy kapłan katolicki byłby fizycznie bądź moralnie niedostępny ${ }^{26}$. Jak długo trwa przeszkoda w dotarciu do szafarza własnego wyznania, tak długo może trwać korzystanie z sakramentalnej gościnności innego Kościoła ${ }^{27}$. Korzystając z gościnności tegoż Kościoła, należy zachować zwyczaje liturgiczne w nim panujące. Katolik pragnący przyjąć Komunię w Kościele wschodnim, aby nie powodować zgorszenia i nieufności, powinien przed Komunią wyspowiadać się i zachować post eucharystyczny ${ }^{28}$.

W poprzednim dyrektorium ${ }^{29}$ znajdował się zapis, na mocy którego zarówno katolicy, jak i chrześcijanie obrządku wschodniego „dla słusznej przyczyny”, tzn. „,z racji pełnienia publicznego urzędu lub obowiązku, z racji pokre-

${ }^{23}$ Nowe dyrektorium ekumeniczne zaleca, aby pasterze pouczali swoich wiernych o szczególnych powodach uczestnictwa w kulcie liturgicznym oraz o odrębnościach dyscyplinarnych poszczególnych wyznań. Zob. PaPieska Rada ds. Popierania Jedności ChrZeściJan, Dyrektorium w sprawie realizacji zasad i norm dotyczacych ekumenizmu (25 marca 1993), dz. cyt., 122.

${ }^{24}$ Por. tamże, 125.

${ }^{25}$ Por. Papieska Rada ds. Popierania Jedności Chrześcijan, Dyrektorium $w$ sprawie realizacji zasad i norm dotyczacych ekumenizmu (25 marca 1993), dz. cyt., 125.

${ }^{26}$ Por. SobÓR WATYKAŃSKI II, Dekret o katolickich Kościołach Wschodnich Orientalium Ecclesiarum, 27, [w:] SobÓR WATYKAŃSKI II, Konstytucje, dekrety, deklaracje, Poznań 2002, s. 185. Dekret w tym punkcie stwierdza również możliwość udzielenia sakramentu pokuty i namaszczenia chorych. Por. także PaPIESKa Rada ds. Popierania Jedności ChrZeściJan, Dyrektorium w sprawie realizacji zasad i norm dotyczacych ekumenizmu (25 marca 1993), dz. cyt., 123.

${ }^{27}$ Por. P. Kantyka, Chrześcijanie przy jednym stole Eucharystii. Możliwości i perspektywy interkomunii, [w:] Eucharystia - Źródło, Szczyt i Życie, red. J. Budzyński, P. Łukasik, K. Mielcarek, Lublin 2005, s. 177.

${ }^{28}$ Por. Papieska Rada ds. Popierania Jedności Chrześcidan, Dyrektorium $w$ sprawie realizacji zasad i norm dotyczacych ekumenizmu (25 marca 1993), dz. cyt., 124.

${ }^{29}$ Sekretariat ds. Jedności Chrześcijan, Dyrektorium do wykonania uchwat Soboru Watykańskiego II w sprawie ekumenizmu, [w:] Ut unum. Dokumenty Kościoła katolickiego na temat ekumenizmu, red. S. C. Napiórkowski, Lublin 1982, s. 112-130. 
wieństwa, przyjaźni lub pragnienia głębszego poznania” mogli uczestniczyć w kulcie liturgicznym tak w jednym, jak i w drugim Kościele ${ }^{30}$. Dyrektorium przewidywało również możliwość przystąpienia na zasadach ogólnych niekatolika do Komunii eucharystycznej w Kościele rzymskokatolickim, a także, na podstawie tych samych zasad, możność uczestnictwa wiernych Kościołów wschodnich w liturgii obrządku łacińskiego ${ }^{31}$. Niestety tych postanowień nie uwzględniono w nowym dyrektorium ekumenicznym.

Mimo bliskości obu Kościołów, jeszcze więcej zastrzeżeń wobec interkomunii prezentuje strona prawosławna. Środowiska prawosławne o bardziej skrajnych poglądach ograniczają przyjmowanie Komunii świętej jedynie do tych, którzy bez żadnych zastrzeżeń akceptują wiarę prawosławną ${ }^{32}$. Ta zasada miałaby także obowiązywać w przypadku, gdy wierny prawosławny przyjmuje Komunię w innej wspólnocie. Oznaczałoby to, że akceptuje on wiarę tej wspólnoty. Takie podejście zdaje się w ogóle wykluczać możliwość interkomunii. Kościół prawosławny twierdzi, że zapraszając do Komunii, nie może oferować uczestnictwa połowicznego, zaprasza on do pełnej łaski i ortodoksji3 ${ }^{33}$. Polski teolog prawosławny J. Klinger uważa, że jeśli Eucharystia to Kościół, w którym wierni przyjmują Ciało i Krew Chrystusa i w którym stają się Jego Ciałem, to przyjmując Eucharystię w innej wspólnocie, „wychodzimy poza własny Kościół” i przez to „stajemy po drugiej stronie podziału”34. Podobnie, gdy chcemy udzielić Komunii we własnym Kościele temu, kto do niego nie należy, to działamy przeciwko swojej wspólnocie.

Prawosławie jest więc przeciwne wszelkim rodzajom interkomunii z racji podkreślania niezmienności istoty Kościoła jako Ciała Chrystusowego. Według teologów prawosławnych Komunia możliwa jest jedynie w Kościele, w którym tkwi przekonanie o tożsamości Eucharystii i Kościoła . To dopiero w niej Kościół staje się rzeczywiście Kościołem Boga ${ }^{35}$. Interkomunia natomiast przeczy kanonicznej jego strukturze. Jednak mimo to, iż prawosławie na ogół nie pozwala swoim wiernym przystępować do sakramentów w innych Kościołach, w sytuacji zagrożenia życia decyzję o poproszeniu o tę posługę księdza katolickiego pozostawia sumieniu wiernego ${ }^{36}$.

${ }^{30}$ Por. tamże, 50 .

${ }^{31}$ Por. tamże, 42 i 43.

${ }^{32}$ Taka Komunia, w której jeden Kościół praktycznie ogranicza udział w Eucharystii tylko do swoich własnych członków, nazywa się „komunią zamkniętą”. Por. W. HANC, Interkomunia - możliwości i perspektywy, art. cyt., s. 106.

${ }^{33}$ Por. P. Nikolski, Eucharystia - taczy czy dzieli? Prawosławny punkt widzenia, [w:] To czyńcie na moja pamiątke, dz. cyt., s. 92-96.

${ }^{34}$ J. KLINGER, O istocie Prawostawia, Warszawa 1983, s. 476-477.

${ }^{35}$ Por. W. HANC, Interkomunia - możliwości i perspektywy, art. cyt., s. 117.

${ }^{36}$ Por. P. NIKOLSKI, Eucharystia - łączy czy dzieli? Prawosławny punkt widzenia, art. cyt., s. 97. 
Kościoły prawosławny i rzymskokatolicki zgodne są co do rzeczywistej i pełnej obecności Chrystusa w Eucharystii. Mimo to jednak nie można osiągnąć konsensusu co do zawartości i założeń tej pełni. Prawosławie naucza, że Chrystus oprócz tego, że jest obecny w sakramencie, staje się obecny również w nauczaniu i życiu swego Kościoła. A ponieważ praktyka sakramentalnej jedności nie jest jednolita w wierze, powoduje to oderwanie w Chrystusie aspektu prawdy od aspektu życiowego i dzieli Jego istotę. To kolejny powód, dla którego w wyznaniu prawosławnym interkomunia jest niemożliwa. Podobnie wzajemne uznanie ważności sakramentów nie stanowi dla Kościoła prawosławnego argumentu za interkomunią. Nie zmienia to bowiem faktu, że w katolicyzmie pozostaje bardzo wiele elementów, na które Kościół ten nie może przystać37.

Kościoły wschodnie nie negują darów duchowych, które istnieją w innych Kościołach, ale nie mogą zgodzić się na pomijanie różnych rozbieżności, które są powodem braku jedności między poszczególnymi wyznaniami. P . Nikolski zauważa, że Eucharystia nie dzieli, ale wskazuje podziały, a tym samym nie pozwala budować jedności na pozornym fundamencie ${ }^{38}$. Pełna interkomunia między Kościołem rzymskokatolickim i Kościołem wschodnim jest wciąż sprawą przyszłości, może już nie tak dalekiej. Patriarcha Konstantynopola Bartłomiej I podczas ostatniego spotkania z papieżem Benedyktem XVI w Turcji powiedział: „Wyznajemy w żalu, że jeszcze nie jesteśmy w stanie sprawować sakramentów w jedności, i modlimy się, by dzień ten jak najszybciej nadszedł"39.

\section{Interkomunia z Kościołami reformowanymi na Zachodzie}

Różnice w wierze dotyczące niektórych aspektów Eucharystii, odmienne podejście do życia sakramentalnego wiernych, a zwłaszcza brak sukcesji apostolskiej sprawiają, że droga do interkomunii z Kościołami i wspólnotami odłączonymi na Zachodzie jest znacznie trudniejsza niż w przypadku Kościołów prawosławnych ${ }^{40}$.

Jan Paweł II w encyklice Ecclesia de Eucharistia przypomina, że sukcesja apostolska w misji pasterskiej zakłada konieczność sakramentu święceń. Wyraża się ona w ciągłości ważnych święceń biskupich i to dzięki niej Kościół istnieje „w sensie właściwym i pełnym” ${ }^{41}$. Sukcesja jest również warunkiem, aby zgromadzenie stało się rzeczywiście wspólnotą eucharystyczną. Kościoły

${ }^{37}$ Por. tamże.

${ }^{38}$ Por. tamże, 99.

39 „Niedziela” 50 (2006), s. 6.

${ }^{40}$ Por. K. Starczewski, Nauka o Eucharystii w wybranych wyznaniach chrześcijańskich i chrześcijańskich dialogach ekumenicznych, dz. cyt., s. 86-90.

${ }^{41}$ Jan PAWE⿺ II, Encyklika Ecclesia de Eucharistia vivit, dz. cyt., 29. 
reformowane nie mówią zaś o sakramencie kapłaństwa, ale o „ordynacji do posługi w głoszeniu słowa Bożego i udzielaniu sakramentów"42.

Sobór Watykański II w Dekrecie o ekumenizmie naucza, że członkowie innych Kościołów ze względu na chrzest znajdują się w rzeczywistej, choć niedoskonałej komunii z Kościołem katolickim ${ }^{43}$. Jednakże Sobór zauważa też, że między Kościołem katolickim i zachodnim istnieją „,bardzo poważne rozbieżności” w odniesieniu do „interpretacji prawdy objawionej” ${ }^{4}$.

Dekret o ekumenizmie Unitatis redintegratio przypomina następnie, że Kościoły na Zachodzie nie zachowały „,autentycznej i całej istoty eucharystycznego Misterium”, głównie przez brak sakramentu kapłaństwa. W związku z tym w opinii Kościoła rzymskokatolickiego, ważność i skuteczność celebrowanej Eucharystii we wspólnotach wyrosłych z Reformacji oraz w Kościele anglikańskim stoi pod znakiem zapytania. Dekret podkreśla więc, że w dążeniu do jedności trzeba zachować roztropność i nie pozwolić na to, aby w działaniach ekumenicznych miało miejsce zafałszowanie prawdy ${ }^{45}$.

Konkretne ustalenia co do szczególnych i wyjątkowych wypadków interkomunii z Kościołami reformowanymi zawiera nowe dyrektorium ekumeniczne. Szafarz katolicki może udzielić sakramentu Eucharystii, pokuty i namaszczenia chorych wiernym z tych Kościołów zawsze w niebezpieczeństwie śmierci, a w innych przypadkach tylko w sytuacji naglącej konieczności ${ }^{4}$. Ewentualność taka może zaistnieć wtedy, gdy osoba dobrowolnie prosząca szafarza katolickiego o udzielenie sakramentu nie ma możliwości otrzymania go od szafarza swojego wyznania. Osoba ta powinna też przejawiać katolicką wiarę w ten sakrament i być należycie do niego przygotowana ${ }^{48}$. Wierny katolik natomiast może prosić o udzielenie tych sakramentów tylko w tym Kościele, w którym są one sprawowane ważnie, z sakramentem kapłaństwa włącznie ${ }^{47}$. Wynika stąd, że wierny powinien posiadać szczegółową wiedzę na temat podejścia swojego Kościoła do

${ }^{42}$ W. Hryniewicz, Czy wspólnota Stołu Pańskiego jest już możliwa?, art. cyt., s. 238.

${ }^{43}$ Por. SobóR WATYKAŃSKI II, Dekret o ekumenizmie Unitatis redintegratio, 15, [w:] SobÓR WATYKAŃSKI II, Konstytucje, dekrety, deklaracje, dz. cyt.

${ }^{44}$ Tamże, 19.

${ }^{45}$ Por. tamże, 24.

${ }^{46}$ Musi się to odbyć zgodnie z zaleceniem biskupa diecezji oraz po spełnieniu określonych wymagań. Por. PAPIESKa Rada ds. Popierania Jedności ChrZeścijan, Dyrektorium w sprawie realizacji zasad i norm dotyczacych ekumenizmu (25 marca 1993), dz. cyt., 130.

${ }^{47}$ Por. Papieska Rada ds. Popierania Jedności Chrześcijan, Dyrektorium $w$ sprawie realizacji zasad i norm dotyczących ekumenizmu (25 marca 1993), dz. cyt., 132. 
ważności sakramentów udzielanych w danej wspólnocie ${ }^{48}$. Jeżeli brak w niej sakramentu święceń, katolik ów nie będzie mógł przyjąć Komuniii" ${ }^{49}$

Zasady nowego dyrektorium potwierdza encyklika Ecclesia de Eucharistia. W Kościele katolickim nie można więc udzielić Komunii świętej osobie, która nie przyjmuje w całości jego prawd wiary dotyczących tajemnicy Eucharystii $^{50}$. To oznacza, że odrzucenie chociażby jednej prawdy wiary dotyczącej sakramentów sprawia, iż „proszący nie posiada dyspozycji, aby zgodnie z prawem można było mu ich udzielić" ${ }^{51}$.

Nowe dyrektorium stwierdza, że w wyjątkowych sytuacjach i pod pewnymi warunkami można się zgodzić, a nawet zalecić, aby „chrześcijanie innych Kościołów i Wspólnot eklezjalnych" zostali dopuszczeni do Komunii eucharystycznej w Kościele katolickim ${ }^{52}$. Dzięki temu realną może się wydawać możliwość, aby gościnność eucharystyczna trwała dłużej, tzn. aż do momentu, gdy szafarz własnego wyznania będzie mógł już bez przeszkód udzielać sakramentów.

Niektóre Kościoły na Zachodzie mimo braku jedności w wierze i bez naglącej potrzeby już dziś praktykują model tzw. „komunii otwartej”53. Tak jest w przypadku Kościoła ewangelicko-augsburskiego, który oświadczył, że wszyscy ochrzczeni, w tym katolicy, zaproszeni są do świętowania Wieczerzy Pańskiej ${ }^{54}$.

${ }^{48}$ Por. P. KANTYKA, Gościnność eucharystyczna wedlug dokumentów Kościoła rzymskokatolickiego, [w:] To czyńcie na moja pamiątkę, dz. cyt., s. 196.

${ }^{49}$ Por. Jan PaweŁ II, Encyklika Ecclesia de Eucharistia vivit, dz. cyt., 46. Należy dodać, iż w odniesieniu do ważności sakramentu święceń nie można ustanowić jednej reguły dla wszystkich Kościołów reformowanych, gdyż np. w Skandynawii istnieją nadal Kościoły luterańskie, które zachowały ważność sukcesji apostolskiej, a co za tym idzie, zachowały one także ważność udzielania sakramentu kapłaństwa oraz sprawowanej Eucharystii. Por. P. KANTYKA, Chrześcijanie przy jednym stole Eucharystii, dz. cyt., s. 179.

${ }^{50}$ Por. JAN PAweŁ II, Encyklika Ecclesia de Eucharistia vivit, dz. cyt., 38.

${ }^{51}$ Tamże, 46.

${ }^{52}$ Papieska Rada ds. Popierania Jedności Chrześcinan, Dyrektorium w sprawie realizacji zasad i norm dotyczacych ekumenizmu (25 marca 1993), dz. cyt., 129. Dotyczy to również sakramentów pokuty i namaszczenia chorych. Przykładem takiej wyjątkowej sytuacji dopuszczenia do Komunii eucharystycznej może być śp. brat Roger, przełożony wspólnoty ekumenicznej z Taizé. Por. R. NIESZWIEC, Eucharystia sakramentem jedności-aspekt historyczny, [w:] Wspólna Eucharystia - cel Ekumenie, red. P. Jaskółka, R. Porada, Opole 2005, s. 86.

${ }^{53}$ Komunia otwarta - przystępowanie do Stołu Pańskiego chrześcijan różnych wyznań. Może ona występować w trzech postaciach: (1) komunia otwarta dla wszystkich (członkowie innych wyznań bez specjalnego zezwolenia są dopuszczani do udziału w Wieczerzy Pańskiej i do komunii); (2) komunia otwarta wzajemna lub obustronna (dwa Kościoły dopuszczają członków jednej lub drugiej strony); (3) komunia otwarta z ograniczeniem (w nagłych wypadkach i za zgodą odpowiednich władz kościelnych dopuszcza się członków innych Kościołów, nie mogących uczestniczyć w interkomunii lub komunii dla wszystkich). Por. W. Hanc, Interkomunia - możliwości i perspektywy, art. cyt., s. 106.

${ }^{54}$ Por. J. NowaK, Perspektywy wspólnej Eucharystii w dialogach, [w:] Wspólna Eucharystia - cel Ekumenii, dz. cyt., s. 246. 
Wspólnoty wyrosłe na gruncie Reformacji pojmują Eucharystię bardziej jako osobową komunię z Jezusem Chrystusem niż jako udział we wspólnocie kościelnej. W związku z tym nie widzą większych przeszkód, aby wraz z katolikami tworzyć wspólnotę eucharystyczną. Kościół ewangelickoaugsburski praktykuje więc „Komunię dla wszystkich w duchu gościnności eucharystycznej”. Z tego też powodu Kościół ten uważa, iż nie powinno się odmawiać także luteranom udziału w Eucharystii w obrządku łacińskim ${ }^{55}$.

Kościół rzymskokatolicki sądzi natomiast, że pomiędzy komunią eklezjalną i eucharystyczną istnieje ścisła, nierozerwalna więź. Komunia eucharystyczna nie jest tylko indywidualną z Chrystusem, ale również z Kościołem, a co za tym idzie, stanowi ona jedność z komunią kościelną. Dlatego też pełna wspólnota pomiędzy tymi wyznaniami trudna jest do urzeczywistnienia.

\section{Nowe inicjatywy ekumeniczne w kierunku interkomunii}

W czasach najnowszych wśród wiernych Kościoła rzymskokatolickiego i wiernych innych Kościołów chrześcijańskich powstało wiele interesujących inicjatyw mających na celu przybliżenie dnia pełniejszej wspólnoty wokół Eucharystii, Testamentu, który zostawił nam Jezus Chrystus ${ }^{56}$. Zastanawiającym jest fakt, że odważniejsze kroki na drodze do wspólnego Stołu Pańskiego podejmowali katolicy w porozumieniu z protestantami. Rozwija się także dialog między Kościołami katolickim i prawosławnym, które, ze względu na wspólne dziedzictwo pierwszego tysiąclecia, winny być bliżej eucharystycznej jedności. Także i te wspólnoty starają się przełamać pewien impas w stosunkach intersakramentalnych

Jeszcze na początku XX wieku Kościoły praktykowały Komunię tylko wewnątrz własnego wyznania w myśl zasady, iż jeśli nie ma pełnej wspólnoty kościelnej, to nie może być mowy, aby istniała prawdziwa wspólnota eucharystyczna ${ }^{57}$. Nadzieja na przywrócenie jedności wokół stołu eucharystycznego pojawiła się wraz z powstaniem ruchu ekumenicznego. Dzięki dialogowi prowadzonemu przez Kościoły chrześcijańskie wyjaśniono, jak poszczególne wyznania rozumieją tajemnicę Eucharystii. Ważne, że dla wszystkich wspól-

${ }^{55}$ Tamże, 246-249. Kościoły luterański i ewangelicko-reformowany uznały, iż Kościół katolicki jest Kościołem Chrystusowym w pełnym tego słowa znaczeniu. Równocześnie jednak wspólnoty te wyraziły nadzieję, że i strona katolicka uzna ich wspólnoty za takowe Kościoły. Oba wyznania były gotowe do podpisania ze stroną rzymskokatolicką porozumienia o wzajemnym dopuszczaniu wiernych do Stołu Pańskiego. Por. W. Hanc, Trudności i przeszkody na drodze ku eucharystycznej petni, [w:] Wspólna Eucharystia - cel Ekumenii, dz. cyt., s. 186.

${ }^{56}$ Por. K. Starczewski, Nauka o Eucharystii w wybranych wyznaniach chrześcijańskich i chrześcijańskich dialogach ekumenicznych, dz. cyt., s. 91-99.

${ }^{57}$ Por. W. Hryniewicz, Czy wspólnota Stołu Pańskiego jest już możliwa?, art. cyt., s. 220. 
not uczestnictwo w jednym Chlebie i jednym Kielichu oznacza i sprawia jedność Kościoła. Niemniej jednak różnice w tłumaczeniu widzialnej jedności Kościoła rodzą trudności w pojmowaniu wspólnej wieczerzy ${ }^{58}$.

Jedną z pierwszych ciekawych, oddolnych inicjatyw ekumenicznych było powstanie w 1937 roku tzw. „grupy z Dombes”59. W 1967 roku odbyło się spotkanie tej grupy poświęcone w całości tematowi Eucharystii i interkomunii. Stwierdzono wówczas, że celem całego ruchu ekumenicznego jest pełna wspólnota eucharystyczna. Grupa z Dombes, zakładając już pewną zgodność dotyczącą wiary, kultu i struktur kościelnych, uznała, że interkomunia powinna stać się etapem na drodze do jedności. W trakcie rozmów zauważono również, że celebracje eucharystyczne w dalszym ciągu są „nosicielkami poszczególnych Kościołów” oraz że ukazują one to, co jeszcze nas dzieli ${ }^{60}$. Spróbowano znaleźć wspólne punkty i zrozumieć różnice w nauczaniu o Eucharystii. Wyjaśniono kwestię pojmowania sposobu obecności Chrystusa w ofierze Mszy świętej. Zwrócono uwagę na poważne rozbieżności poglądów dotyczących „trwania obecności Chrystusa” w tym sakramencie. Równocześnie zauważono, iż „Kościół katolicki uznaje Eucharystię w Kościele prawosławnym, nie żądając od niego sprecyzowanej teologii obecności i transsubstancjacji”. Wyjaśniono także sposób rozumienia Mszy świętej jako ofiary Chrystusa. Ponadto stwierdzono, że protestanci zaczynają dowartościowywać sakramenty, a katolicy rozważniej przepowiadają tajemnicę eucharystyczną. Największą trudność sprawił temat sukcesji apostolskiej w biskupstwie. Zauważono jednocześnie, że w protestantyzmie sukcesja coraz częściej widziana jest jako znak „ciągłości i trwania misterium”, a u katolików wzrasta świadomość „,instrumentalnego i funkcjonalnego charakteru kapłaństwa oraz kościelności wspólnot wyrosłych z Reformacji”'61.

Nowe rozwiązania w odniesieniu do interkomunii próbował znaleźć tzw. raport z Malty (1972) będący owocem pracy katolicko-luterańskiej komisji studiów ${ }^{62}$. W dokumencie stwierdzono, że wspólna Eucharystia jest

${ }^{58}$ Por. tamże, 236-237.

${ }^{59}$ Jej założycielem był Paul Couturier. W skład grupy weszli katolicy, liczni reformowani i nieliczni luteranie. Nazwa grupy pochodzi od miejsca pierwszych spotkań, które odbywały się w klasztorze trapistów w miejscowości Dombes $40 \mathrm{~km}$ od Lyonu. Pomimo to, że nikt nie udzielał tej grupie kościelnych upoważnień, Kościoły do dziś nie lekceważą jej tez i uzgodnień. Por. S. C. Napiórkowski, Eucharystia w dialogu. Uzgodnienia Grupy z Dombes, RTK KUL 24 (1977) z. 2, s. 29-30.

${ }^{60}$ Por. tamże, 32-33.

${ }^{61}$ Tamże, 34-35.

${ }^{62}$ Raport Luterańsko-Rzymskokatolickiej Komisji Studiów Ewangelia a Kościół (1972), [w:] Bliżej wspólnoty. Katolicy i luteranie w dialogu 1965-2000, red. K. Karski, S. C. Napiórkowski, Lublin 2003, s. 39-67. 
prawdziwym znakiem jedności Kościoła. Sakramentu Eucharystii nie da się „oddzielić od wiary w Chrystusa i Jego eucharystycznej obecności oraz od wspólnoty Kościoła" ${ }^{3}$. Autorzy raportu przede wszystkim zwrócili uwagę na to, że nie można utożsamiać jedynego Kościoła Chrystusa z Kościołem rzymskokatolickim. Jedność w Kościele rzymskokatolickim nie jest więc zupełna, ale zmierza dopiero ku pełnej jedności, którą osiągnie wówczas, gdy wszyscy zaproszeni na eucharystyczną wieczerzę, będą mogli w niej uczestniczyć. Dokument podkreśla, że Wieczerza Pańska, w której wierzący i ochrzczeni nie mogą brać udziału, „kryje w sobie wewnętrzną sprzeczność” $\mathrm{i}$ jest niezgodna $\mathrm{z}$ tym, co polecił nam Chrystus.

Komisja zdaje sobie sprawę $\mathrm{z}$ tego, że jedności nie można przywrócić od razu, ale to nie zmienia faktu, że trzeba szukać drogi wyjścia z impasu. Postuluje więc umożliwienie interkomunii przy okazji różnych spotkań ekumenicznych czy w przypadku małżeństw mieszanych. Stwierdza, że urzeczywistnienie wspólnoty eucharystycznej nie powinno być bezwzględnie uzależnione od faktu uznania urzędu kościelnego. Należy pamiętać przede wszystkim o sytuacji wiernych, którzy poprzez udział w uroczystościach Wieczerzy Pańskiej szukają wspólnoty w Chrystusie ${ }^{64}$.

Raport z Malty nie rozwiązał wprawdzie problemu wspólnej Eucharystii, ale dzięki niemu stworzony został właściwy klimat do dalszych rozmów. Przedstawiono w nim konkretne możliwości zastosowania interkomunii w szczególnych okolicznościach. Chodzi tu m.in. o wspomniane wyżej spotkania ekumeniczne i małżeństwa mieszane, a także o praktykę interkomunii, która mogłaby zaistnieć za zgodą władz kościelnych. Interkomunia mogłaby być praktykowana z zastrzeżeniem, aby nie wprowadzać w błąd wiernych.

Najnowszą ekumeniczną inicjatywą w sprawie interkomunii jest wydanie w roku 2003 przez katolickie i ewangelickie instytuty badań ekumenicznych w Niemczech dokumentu pt. Wspólnota Wieczerzy Pańskiej ${ }^{65}$. Traktując o gościnności eucharystycznej, dokument sugeruje, że interkomunia staje się dziś w wielu przypadkach pożądana i wskazana.

W apelu zamieszczonym na samym początku dokumentu autorzy wyjaśniają, że ich celem jest pobudzenie na nowo dyskusji na temat wspólnej praktyki eucharystycznej. Pragną oni udokumentować i uzasadnić, iż gościnność eucharystyczna jest naprawdę możliwa w stosunku do „małżeństw i rodzin o różnej

${ }^{63}$ Tamże, 69.

${ }^{64}$ Tamże, 73-74.

${ }^{65}$ Wspólnota Wieczerzy Pańskiej jest możliwa. Tezy w sprawie gościnności eucharystycznej, [w:] „Studia i Dokumenty Ekumeniczne” 2 (2003), s. 78-86. Dokument został opracowany i wydany przez Instytut Badań Wyznaniowych Związku Ewangelickiego w Benhaim, Instytut Badań Ekumenicznych ŚFL w Strasburgu oraz Instytut Badań Ekumenicznych Wydziału Teologii Katolickiej Uniwersytetu w Tybindze, ukazał się 7 kwietnia 2003 roku. 
przynależności konfesyjnej”, a także członków różnych grup ekumenicznych oraz chrześcijan, którzy uczestniczą w nabożeństwach innego wyznania. Dopuszczanie do gościnności eucharystycznej tych, którzy praktykują wspólnotę eucharystyczną, nie jest już ograniczone przyczynami teologicznymi ${ }^{66}$.

Autorzy Wspólnoty Wieczerzy Pańskiej uważają wręcz, że „to nie fakt dopuszczenia ochrzczonych chrześcijan do wspólnej Wieczerzy Pańskiej, lecz niedopuszczenie do niej wymaga uzasadnienia"67. Na podstawie teologicznego twierdzenia, że jedność jest nam dana z góry w Chrystusie, zrodziło się przekonanie, iż na rozłamy w Kościele należy spojrzeć w nowej perspektywie. Mimo że w Kościołach prawosławnym, rzymskokatolickim i niektórych protestanckich praktykowana jest nadal komunia zamknięta, należy stopniowo wprowadzać w życie wspólną Wieczerzę Pańską.

Brak jedności eucharystycznej we wspólnotach ekumenicznych powoduje znaczne osłabienie ich wiarygodności, twierdzą autorzy w drugiej tezie dokumentu. Coraz więcej ludzi bowiem nie rozumie, czemu chrześcijanie, czerpiąc z tych samych źródeł, uczestniczą w Wieczerzy Pańskiej tylko w obrębie własnej wspólnoty ${ }^{68}$. W kolejnej tezie twórcy dokumentu przypominają, że już dziś, w wyjątkowych wypadkach, dopuszcza się gościnność eucharystyczną w odniesieniu do pojedynczych osób. Bramę do wspólnoty Kościoła stanowi chrzest, włączając ochrzczonych w Ciało Chrystusa i dlatego jest on warunkiem dopuszczenia do Wieczerzy Pańskiej ${ }^{69}$.

Dokument podkreśla, że Kościół w stosunku do uroczystości eucharystycznej pełni funkcję służebną, ponieważ to Chrystus jest Dawcą i Darem, i to On zaprasza do wieczerzy ${ }^{70}$. Konsekwencją takiego stanowiska jest następna odważna teza dokumentu głosząca, że „wspólnota Wieczerzy Pańskiej sięga dalej niż wspólnota kościelna"71. Autorzy dokumentu Wspólnota Wieczerzy Pańskiej rozwijają tę myśl, twierdząc, że nie trzeba akceptować konkretnego, historycznego kształtu Kościoła, ale przyjąć elementy zwiastowania, nabożeństwa i służby dla świata, które formują jego życie. Zgodnie ze słowami Nowego Testamentu, Kościół poznaje się po tym, że ludzie trwają w „nauce apostołów i we wspólnocie, w łamaniu chleba i na modlitwie”.

\footnotetext{
${ }^{66}$ Por. tamże, s. 78.

${ }^{67}$ Tamże, teza 1.

${ }^{68}$ Por. tamże, teza 2.

${ }^{69}$ Por. tamże, teza 3 i 4.

${ }^{70}$ Por. tamże, teza 5.

${ }^{71}$ Słowo i sakrament, przez które działa Bóg, stanowi podstawę Kościoła i jego jedności. Poprzez to działanie wyznawcy Chrystusa stają się w każdym czasie jednością zarówno w Nim, jak i między sobą. Twórcy dokumentu zauważają także, iż Wieczerza Pańska nie istniałaby bez konkretnej wspólnoty jakiegoś Kościoła, ale - co wydają się bardziej podkreślać - gdyby nie Boże działanie, nie byłoby ani Kościoła, ani Wieczerzy Pańskiej. Zob. tamże, teza 6.
} 
Od tych najistotniejszych elementów winno się odróżnić formy konfesyjne, które dopuszczają różnorodnośćc ${ }^{72}$.

W końcowej części (teza 7) dokument Wspólnota Wieczerzy Pańskiej omawia sytuację interkomunii między Kościołem katolickim a Kościołami wyrosłymi z Reformacji. Stwierdza się w niej, że między tymi Kościołami istnieje zgodność co do głównych prawd wiary, których podstawą jest życie i dzieło Chrystusa oraz Biblia ${ }^{73}$. Według autorów dokumentu osiągnięto już daleko idącą zgodność w rozumieniu Wieczerzy Pańskiej i z tego powodu różnice, które jeszcze istnieją, nie mogą stanowić przeszkody we wspólnej celebracji eucharystycznej ${ }^{74}$. Do tych różnic należy problem sukcesji apostolskiej. Kościoły i wspólnoty protestanckie w zasadzie nie podważają posługiwania i święceń w Kościele katolickim. Ten jednak, ze względu na zarzut niezachowywania sukcesji apostolskiej, ma zastrzeżenia do ważności posługiwania duchownego oraz do święceń udzielanych we wspólnotach poreformacyjnych. Inną przeszkodą w dialogu jest dopuszczanie kobiet do święceń kapłańskich przez niektóre Kościoły wyrosłe z Reformacji ${ }^{75}$.

W podsumowaniu autorzy dokumentu Wspólnota Wieczerzy Pańskiej wyrażają pogląd, że gościnność eucharystyczna, pomimo niepełnej „zgodności poglądów w rozumieniu Eucharystii urzędu i Kościoła”, jest realna. Prowadzony dalej dialog może przyczynić się do wspólnego ukształtowania Eucharystii. Tam gdzie wspólnota jest możliwa, należy już praktykować wspólną Wieczerzę Pańską. Natomiast różnice, które zachodzą między wyznaniami, mogą przyczynić się do ubogacenia liturgii. Dokument sugeruje również, że w odniesieniu do Eucharystii w jednakowy sposób należałoby traktować zarówno członków własnego Kościoła, jak i korzystających z gościnności eucharystycznej ${ }^{76}$.

Wśród części teologów katolickich zajmujących się ekumenizmem zaczyna zwyciężać przekonanie, że warunkiem przystąpienia do Stołu Pańskiego powinno być przyjęcie sakramentu chrztu ${ }^{77}$. W chrzcie tak jak i w Eucharystii, mamy do czynienia z tym samym Chrystusem. Ci, którzy uczestniczą w Wieczerzy Pańskiej, stają się tym samym Ciałem, w które zostali wszczepieni podczas chrztu. Jednak chrześcijanie, którzy w swoim Kościele przyjęli ten pierwszy sakrament wtajemniczenia, nie mogą uczestniczyć w celebracji eucharystycznej innych wspólnot. Dzieje się tak dlatego, że w poszczególnych Kościołach

\footnotetext{
${ }^{72}$ Por. tamże, teza 7.

${ }^{73}$ Por. tamże, teza 7.1 .

${ }^{74}$ Por. tamże, teza 7.2.

${ }^{75}$ Por. P. KantyKa, Chrześcijanie przy jednym stole Eucharystii, art. cyt., s. 182.

${ }^{76}$ Por. Wspólnota Wieczerzy Pańskiej jest możliwa, dz. cyt., s. 84-86.

${ }^{77}$ Por. W. Hryniewicz, Czy wspólnota Stołu Pańskiego jest już możliwa?, art. cyt., s. 223.
} 
relacje wobec Ciała Chrystusa i widzialnej wspólnoty wierzacych rozumiane są inaczej. Usprawiedliwia się to rozbieżnościami doktrynalnymi. Przy sprawowaniu wspólnej Eucharystii wymagane jest pełne uznanie posługiwania z mocy święceń i zgodność wiary z nauką własnego wyznania ${ }^{78}$.

Tymczasem, jak zauważa ks. Wacław Hryniewicz, często zapomina się o tym, iż Kościoły są zgodne w kwestii rozumienia centralnych prawd wiary, do których należą „prawda o Bogu Trójjedynym oraz o Jezusie Chrystusie, Bogu-Człowieku”. Oprócz nich istnieją jeszcze ,prawdy dotyczące porządku zbawienia w czasie ziemskiego pielgrzymowania Kościoła", do których zaliczyć trzeba liczbę sakramentów, hierarchiczną strukturę Kościoła i sukcesję apostolską. Według Hryniewicza sposób wyrażania wspólnej wiary w Jezusa Chrystusa jako Zbawiciela nie musi być powodem podziału Kościoła, gdyż więcej jest we Wspólnotach tego, co łączy, niż tego, co dzieli ${ }^{79}$. Ta sama wiara w podstawowe prawdy chrześcijańskie, sakramentalna jedność w chrzcie i Eucharystii oraz kościelne ministerium jako posługa na rzecz jedności Kościoła Chrystusowego już teraz mogą stać się wspólną drogą ku komunii Kościołów chrześcijańskich ${ }^{80}$.

Kościół katolicki stoi na stanowisku, że pełna gościnność eucharystyczna nie jest dla chrześcijan środkiem do osiągnięcia jedności, ale jest jej ostatecznym celem ${ }^{81}$. Wspólnota wokół Stołu Pańskiego ma świadczyć o pełnej jedności w wierze. Stosowanie pełnej interkomunii nie może być więc drogą do usunięcia różnic w wierze, ale musi być szczytem jedności w jej wyznawaniu. Dlatego też z punktu widzenia katolików praktykowanie współudziału w Komunii eucharystycznej jako środka do osiągnięcia jedności eklezjalnej nie przybliża, ale oddala zjednoczenie chrześcijan ${ }^{82}$.

Kościoły wyrosłe z Reformacji twierdzą natomiast, że „wspólnota Stołu Pańskiego nie jest jedynie uwieńczeniem pełnej jedności Kościoła”, gdyż w Eucharystii otrzymujemy także umocnienie na wspólnej drodze ku jedności. To sprawia, że nawet w chwilach zagrożenia wspólnota jest podtrzymywana przez Wieczerzę. Stół Pański według protestantów pobudza dążenie do jedności. Dzięki temu chrześcijanie, którzy uczestniczą w celebracji eucharystycznej innego Kościoła, mogą ufać, że Chrystus także im udziela się w swoim Ciele i Krwi ${ }^{83}$.

\footnotetext{
${ }^{78}$ Por. tamże, s. 228.

${ }^{79}$ Por. tamże, s. 237.

${ }^{80}$ Por. W. Hanc, Trudności i przeszkody na drodze ku eucharystycznej petni, art. cyt., s. 194.

${ }^{81}$ Por. P. KantYKa, Gościnność eucharystyczna wedtug dokumentów Kościoła rzymskokatolickiego, art. cyt., s. 199.

${ }^{82}$ Por. JAN PAWEe II, Encyklika Ecclesia de Eucharistia vivit, dz. cyt., 30.

${ }^{83}$ Por. W. Hryniewicz, Czy wspólnota Stołu Pańskiego jest już możliwa?, art. cyt., s. 232.
} 


\section{Interkomunia w encyklice Ecclesia de Eucharistia}

\section{i nadzieje na przyszłość}

Papież Jan Paweł II w encyklice Ecclesia de Eucharistia, która ukazała się dziesięć dni po wydaniu dokumentu Wspólnota Wieczerzy Pańskiej, wykluczył możliwości wspólnej Wieczerzy pomiędzy katolikami i protestantami, argumentując, że różnice dotyczące nauki wiary między tymi wyznaniami są jeszcze zbyt duże ${ }^{84}$. Papież negatywnie odniósł się też do praktyk nieskrępowanej interkomunii. Encyklika Ecclesia de Eucharistia stwierdza, że chociaż w indywidualnych przypadkach praktyka gościnności eucharystycznej jest możliwa, jej celem ma być jednak „,zaspokojenie poważnej potrzeby duchowej dla zbawienia wiecznego poszczególnych wiernych", a nie realizacja interkomunii, która będzie niemożliwa aż do czasu pełnej jedności Komunii kościelnej ${ }^{85}$.

Z punktu widzenia Kościoła rzymskokatolickiego we „wspólnotach kościelnych powstałych na Zachodzie w XVI wieku i odłączonych od Kościoła katolickiego" Eucharystia sprawowana jest bez zachowania "autentycznej i całej istoty eucharystycznego Misterium" ${ }^{\text {"6 }}$. Powodem tego jest brak sukcesji apostolskiej, a tym samym sakramentu kapłaństwa oraz brak jedności eklezjalnej z biskupem Rzymu ${ }^{87}$.

Hryniewicz sądzi, że prymat papieski nie stoi na przeszkodzie w drodze do wspólnej celebracji eucharystycznej, gdyż Kościół rzymskokatolicki uznaje ważność Eucharystii sprawowanej w wyznaniu prawosławnym, gdzie przecież wspólnota z papieżem nie istnieje ${ }^{88}$.

Próbą przełamania impasu w braku pełnej wspólnoty eucharystycznej może więc być perspektywa rozmów dotyczących zagadnienia odnowienia sukcesji apostolskiej, a co za tym idzie, uznania ważności posługiwania duchownego i święceń oraz ważności Eucharystii. To spowodowałoby, że Kościoły i wspólnoty wywodzące się z Reformacji byłyby w podobnej sytuacji co Kościoły wschodnie, w których zarówno sukcesja apostolska, jak i sakramenty nie są kwestionowane ${ }^{89}$.

Gdyby wszystkie Kościoły wzajemnie uznały sukcesję i sakramenty, a zwierzchnicy tych Kościołów zgodzili się przyjąć, że różnice w wierze i ustroju kościelnym nie wykluczają wspólnoty Stołu, droga do interkomu-

\footnotetext{
${ }^{84}$ Por. Jan PaweŁ II, Encyklika Ecclesia de Eucharistia vivit, dz. cyt., 38, 44, 46.

${ }^{85}$ Por. tamże, 45.

${ }^{86}$ Tamże, 30.

${ }^{87}$ Por. tamże, 28, 30, 39, 44, 46.

${ }^{88}$ Por. W. Hryniewicz, Czy wspólnota Stołu Pańskiego jest już możliwa?, art. cyt., s. 244.

${ }^{99}$ Por. P. KantYKA, Chrześcijanie przy jednym stole Eucharystii, art. cyt., 182-183.
} 
nii byłaby otwarta. Dzięki temu uznanie przez Kościół katolicki jedności z biskupem Rzymu jako elementu strukturalnego Kościoła partykularnego również nie byłoby przeszkodą. Ponadto, skoro wyjątki w dopuszczaniu do interkomunii oparte są na przesłankach teologicznych, a nie pozateologicznych, to te same racje (przesłanki) mogłyby posłużyć do opracowania norm bardziej generalnych. Warto też wziąć pod uwagę, że to nie wspólnota czy poszczególni wierzący są gospodarzami Eucharystii, lecz jest nim sam Chrystus. To On jako Dawca i Dar zaprasza na wieczerzę, a Kościół jedynie pośredniczy w tym zaproszeniu ${ }^{90}$.

Przedstawione wyżej odważne inicjatywy grup katolicko-protestanckich w zakresie interkomunii mogłyby stać się inspiracją dla podobnych działań w spotkaniach katolików z chrześcijanami tradycji wschodniej, z którymi przecież więcej nas łączy, niż dzieli. Uwzględniając wszelkie odmienności obu wyznań i przestrzegając zasad wzajemnej gościnności, poprzez spotkania pasterzy Kościołów, ich wiernych i teologów, wymianę myśli oraz doświadczeń, trzeba nam aktywnie przybliżać dzień spotkania przy wspólnym Stole Pańskim.

Kraków

PRZEMYSEAW NOWAKOWSKI CM

\section{Summary}

The Roman Catholic Church in search of intercommunion with other liturgical traditions Churches

After the Second Vatican Council the Roman Catholic Church recapitulated all his teaching on the Holy Eucharist, coming back to its biblical and patristic roots. At the same time Church was looking for the best way to common Eucharistic Table with different Christian communities - eastern and western. The intercommunion exists just between Catholics and Orthodox in the very special situations. The intercelebration is not possible yet in the absence of ecclesiological and doctrinal communion. The lack of apostolic succession and the other interpretation of the sacraments causes more difficulties on the way to intercommunion with Protestants. A lot of popular initiatives are taken recently in order to make the common Eucharist closer. Protestant Churches regards the practice of intercommunion as one of the means to the complete union among Christians. The Roman Catholic Church emphasizes that intercommunion is just to be an ultimate aim of the Churches union.

${ }^{90}$ Por. tamże, 183-185. 